\title{
Establishing a Community of Inquiry
}

\author{
Paul A. Wagner \\ Department of Leadership and Policy Analysis, College of Education, University of Houston, Clear Lake, Houston, Texas, USA \\ Email: wagner@uhcl.edu
}

How to cite this paper: Wagner, P. A. (2020). Establishing a Community of Inquiry. Creative Education, 11, 1047-1054. https://doi.org/10.4236/ce.2020.117076

Received: May 26, 2020

Accepted: July 17, 2020

Published: July 20, 2020

Copyright $\odot 2020$ by author(s) and Scientific Research Publishing Inc. This work is licensed under the Creative Commons Attribution International License (CC BY 4.0).

http://creativecommons.org/licenses/by/4.0/

\begin{abstract}
Humans are unique among all herd species in their capability to learn to be better cooperators. That capability amplified by a richly textured language including the extraordinary invention of promising, made it possible for humans to construct extraordinarily complex and sophisticated structures of inquiry and cooperation. Preparation for optimizing this capability into realized abilities is afforded through an education that that moves human instinct for cooperation and learning through to a community of inquiry at many levels. Communities of inquiry listen, learn and benefit from one another.
\end{abstract}

\section{Keywords}

Promising, Herd Instinct, Capability V. Ability, Cooperativeness, Defectors, Dispositions, Truth, Truth-Seeking, Skills, Signaling, Confirmation Bias

\section{Evolution}

One cannot create effective education or develop a community of inquiry if one has no appreciation for the evolutionary psychology that led to humans being capable of building and sustaining communities of inquiry; communities that have sufficient language resources, respect for other truth-seekers, sympathies, skills and dispositions for creating and sustaining communities of inquiry. The socio-moral event of promising being perhaps the most fundamental of all of these since it entails attention to all the others.

Human beings are herd animals. Like gazelles, lions, coyotes sheep, ants, bees, schools of fish and gaggles of geese, evolution preserves the species through adaptations of signaling equipping herd animals for cooperative engagements with one another (Wiley, 2015). Humans are master cooperators largely by instinct (Pfaff, 2015; Nowak, Sasaki, \& Fudenberg, 2004; Sigmund, Hauert, \& Nowak, 2001). Admittedly, they are tribalistic and self-interested as well. 
Human cooperativeness gives rise to things like property and transfer of goods over generations and across geographic borders. The turning point catapulting human cooperativeness far beyond anything evident in any other species was the co-development of language (Chomsky, 2016) and the social institution of the promise (Wagner et al., 2018: Ch. 5).

The human brain outgrew the species' need for survival (Mlodinow, 2015). The brain of homo sapien sapiens is so large it is costly in terms of energy expenditure. Fully $20 \%$ of the average human's daily energy expenditure goes to maintaining the functioning brain. The brain outsized itself before evident adaptationist need. Some propose that religious speculation and subsequent abstract speculations may have been one way the earliest humans accommodated the energy costs of this outsized brain (Pinker, 1994; Tomasello, 2014). For example, the earliest manmade structure known to anthropologists seems to be a temple for religious sacrifice in Gobekli Tepe in Turkey and cave-dwelling art suggests other abstractions not needed for survival (Mann, 2011; Curry, 2008; Balter, 1998).

The promise is the most extraordinary social device richly-textured human communication ever produced. The promise creates moral obligation and extends cooperative capacities into realizable abilities.

All currency interactions are instances of promising. Weddings are promising events. Collaborative work in all STEM subjects, sports teams, business finance and so much else all depend largely on the capacity of human, promise-keeping practices.

In short, with language in hand and all the moral accouterments that accompany promising, evolution created the conditions of community and more specifically advanced the emergence of communities of shared inquiry.

But there may be limits to the human range of cooperativeness. For example, herd animals have limitations including an inability to work together when herd size out grows capacity for cooperation. In the case of humans, villages and think tanks and other communities of scholars are examples wherein shared engagement works reasonably well (Pfaff, 2015). In contrast, the League of Nations failed. Small nations such as in Scandinavia are often touted for their ability to work well together. In contrast, large nations such as Brazil, China, Russia, the United States all seem to wrestle with growing tribalism within. Even mid-sized nations such as Egypt, France, Germany, Iran, Italy and Turkey all seem to be unsettled at times by growing tribalism, "we v. they" oppositional forces seeking political power.

Maybe tribalism is unavoidable. However, some mid-sized nations such as Japan do well maintaining universal rituals, cooperation and collaboration. Maybe the antidote in the face of a drift towards tribalism is to emphasize public education based on shared virtues conducive to cooperation and collaboration.

Schools promoting shared rituals may create ground-swell commitment to keeping larger communities together (Garrison, 2016). If the instinct to cooperate and collaborate is nurtured, perhaps the competing instinct towards tribalism will proportionately weaken. 


\section{Learning Classroom Management from Evolutionary History}

Educators know well that class size is important to student learning success (Glass, 2016). This hints at the evolutionary benefits of ritual, cooperation and collaboration since shared classroom success involves working together. On the other hand, while teachers rail against bullying, they often overlook as inevitable, the forming of cliques. Favored affiliations such as cliques are certainly natural. But they serve the emergence of tribalism, and co-opt the counter-balancing instinct of cooperativeness.

Even if teachers neutralize harm from clique groupings, there is no reason to conclude that what a teacher succeeds in bringing about in a classroom can change an entire school, adrift in student "we v. they", thinking. And, even if a school were to work wonders as a harmonious incubator of decency, cooperation, harmony and well-meaning regard towards all is there any reason to suppose that could transfer to other schools in a district, a city, a state or a nation?

There might be a chance (Sanderson, 2020). For such a chance to be realized, schools must give up being factories manufacturing satisfactory, standardized test scores (Chomsky \& Robichaud, 2014: pp. 54-56). Measuring accountability in various matters from time to time is no doubt important. But things are seriously haywire when producing standardized test scores becomes the driving force in education (Ravitch, 2009). In education, accountability practices must not interfere with making every school a community, more specifically, a community of inquiry.

Schools as communities of inquiry prepare students for participation in The Great Conversation of Humankind. The Great Conversation of Humankind is about serving all humans and excluding no one. So, for the good of neighborhoods, nations and the world, instincts for cooperation and collaboration in a community of inquiry must be nurtured at the expense of tribalism.

The general features of the Great Conversation are as follows. First, focus on truth-seeking. Now, and later when students enter the Great Conversation, participants strive to know that they know. Second, in the Great Conversation every fellow truth-seeker is welcome. Third, because truth is the ideal, critical thinking and a healthy dose of skepticism pervade every instance of the Conversation. Fourth, there is no room in the Conversation for prejudice of any kind. Respect for each participant is a must. Fifth, even confirmation bias should be targeted as an avoidable lapse in judgement. Sixth, in The Great Conversation there is no room for propagandizing or trying to manipulate others for personal gain. Seventh, The Conversation is about great things and should never be confused with mere conversation focused on the immediate or, the mundane. (Searching for one's keys is important but it doesn't normally entice one to consider the questions that the big brain of humans is especially talented at exploring.) In The Great Conversation, questions such as "How do you know?" and "What do you mean by that term?" should always be welcomed and appreciated. 
In the Great Conversation people at every age, communally explore the nature of the universe, why is there something rather than nothing, what is happiness, love or the best form of government or, the purpose of education. In short, whenever humans delve into deep matters with an open mind and welcome constructive criticism they are engaged in a moment of The Great Conversation (Jackson, 2011). You are participating in The Great Conversation simply by reading this attentively.

Creating a community of inquiry in the schools directs development of dispositions and skills making a lifetime of participation in The Great Conversation a palpable possibility for each student.

\section{Individual Dispositions}

Evolution teaches that when species develop lethal traits in the face of changing surrounds, the species dies. Indeed, there were apparently a couple of times in evolutionary history when humans very nearly went extinct as their adaptational abilities seemed to wane for the time and place (Mlodinow, 2015; Weisdorf, 2005). Once humans adapted to their over-sized brains and the richly-textured language such brains afforded, cooperation and collaboration through promising practices, made humans a learning species more potent than any other to date. Assuming this to be true, the central pedagogical question for now is not to ask how to motivate students but rather to ask what in a nation's schools is driving students away from formal opportunities to learn, to participate in a community of inquiry.

Think about it. How often do people stand in line at a grocery store and read tabloids by the cash registers? How many times do people at breakfast read a newspaper, a book or even the back of a cereal box?

Humans are unable to deny an inclination towards learning (Gopnik, 2016; Gopnik, 2009; Gopnik, Meltzkoff, \& Kuhl, 1999). Brains evolved then sought out stimuli for learning (Balter, 1998; Curry, 2008). If students are not attentive in schools it is not because they lost their instinct to learn! Instead, it appears the schooling system itself is suffocating the learning instinct. Schools should nurture an ambience for the natural learning instinct to flourish in every student (Henrich, 2015).

\section{Community Dispositions}

From a very early age humans are fairly well-equipped for entering into a community of inquiry (Gopnik et al., 1999). Evolutionary scientists designate this tendency as a key identity of early humans (Tomasello \& Call, 1997), prompting mathematical biologist, Martin Nowak to declare humans the "super cooperators (2014)". This focus on community is the focal point of multiculturalism and fosters respect for all who participate.

To sustain schools as communities of inquiry requires nurturing a sense of wonder among students-and, teachers. It is one thing to wonder alone but 
wonderment is amplified in exciting ways when it is shared with others who equally delight in wonderment (Siu, 2020: esp. ch. 7). In reviewing curriculums endorsing various instructional strategies it seems that the philosophy for children approaches (Fair et al., 2015) and the discovery learning approaches in science education (Rakow, 1986) have been particularly successful in developing a shared spirit of wonderment in their respective communities of inquiry. These are practical approaches exploiting natural human tendencies to learn.

Equally practical, communities of inquiry must explicitly honor the spirit of truth-seeking in every participant. It is instructive to note that even the great pragmatists from James, Pierce and Dewey to Quine, Putnam and Scheffler (Wagner \& Simpson, 2008: ch. 2) were motivated by a desire for epistemic certainty and identified plausibility and utility as standards for action as the search for truth continues.

Finally, another disposition for fostering schools as communities of inquiry is to aim students in the direction of developing personal autonomy. As personal autonomy develops, the drift towards tribalism diminishes.

\section{Individual Skills}

Dispositions and skills are different sorts of things. Dispositions are things people are likely to do under certain conditions. Skills are something people can deliberately employ. Social psychologists such as Daniel Kahneman (2011), Thomas Gilovich \& Lee Ross (2015) along with economists such as Richard Thaler (2015) and anthropologists Michael Tomasello (2009) each recognize a distinction between mere cognitive activity and deliberative thinking necessary for any community of inquiry. Most social and cognitive psychologists today utilize Kahneman's distinction between thinking fast and thinking slow. Thinking fast is moment to moment thinking. Thinking slow is characteristic of shared inquiry and personal evaluative, deliberation. Acquired intellective dispositions and skills enable the human instinct for learning to distinguish between times and contexts when each type of thinking is most likely to lead to apt performances (Sosa, 2009).

Skills for thinking slow include semantic exactness, orderly assembling of assumptions and evaluation of evidential relevancy recognizing that sound conclusions depend on plausible arguments and theoretical constructions. In a community of inquiry, students learn the difference between aiming mere opinion at others and explanations securing agreement on assumptions and plausible evidence to reach a rational conclusion.

Cognitive dissonance lures students to take a position that appears favored early on in community inquiry. However, early consensus is then disrupted by a teacher's skillful question or description of an episode in apparent conflict with what was said previously. In the Great Conversation the point is not simply to air opinions willy nilly but to create sufficiently plausible conclusions others should adopt if reasonable grounds for common assent exist (Jackson, 2011). Communities of inquiry are the threshold to participating in The Great Conversation of all of Humankind. 


\section{Community Skills}

On almost day in any large school, two types of discussions can be found. Both are seriously flawed. Each discourages student learning and autonomous development. In the first, students are encouraged to participate but only until someone arrives at "the right answer". Students quickly learn seeking instructor approval is all that matters and not securing truth approximate or otherwise. In the second type of discussion teachers announce, "There are no right or wrong answers to what we are about to discuss." Obviously, this announcement declares that the activity ahead is pointless.

There can be no progress if there are neither right nor wrong answers. To be productive, discussions must at least hold out hope that some common errors may be identified and avoided in subsequent thinking. The educational psychologists (Gopnik, Meltzkoff, \& Kuhl, 1999) long ago disparaged both these approaches to classroom discussions. To be productive discussions must at least hold student hope that something productive can be learned even if it is no more than the avoidance of contradiction, ambiguities and such (Wagner et al., 2018).

I once gave a presentation on the nature of truth to a group of science educators at one of the nation's largest and most prestigious universities. I explained that the search for truth must always hold promise that some prior error can be eliminated. The science educators present were appalled since all were relativistic in their thinking. Fortunately, the dean of the school of engineering was present. The dean stood up and told the science educators that they needed to walk across campus sometime and meet students in engineering. Engineering students he explained, know when they get things wrong. Their buildings collapse, their bridges fall down, their nuclear reactors crack and so on. Engineers don't have grand cosmic truths at their disposal but they sure know a lot of what doesn't work and they incorporate that knowledge in plans and arguments to construct things that are most likely to work. A professor of physics spoke up in further support and said the science educators will find the same thing in the physics department. Even such speculative theories as string theory he explained, are held forth for plausibility and evaluation and not just as another guess or mere opinion. As in science this is as it is in the sociology of The Great Conversation generally. In contrast, in public school classrooms when teachers announce there are no right or wrong answers, they are discrediting the effort of students to participate before the discussion even begins.

When establishing a community of inquiry all depends on the participants" sincere and passionate desire to search for truth and shared understanding. The sense of wonderment philosophy for children advocates so often talk about is predicated on the idea that there is a worthy understanding of some sort that can be sought (Fair et al., 2015: pp. 14-15). Establishing a community of inquiry means acknowledging we don't know everything relevant to the topic at hand. A community of inquiry because it seeks truth, remains forever gently and modestly skeptical of any and all conclusions. 
In a genuine, community of inquirers, it is understood that participants have inescapable fallibilities and Grand Truth is not in the offing. However, in any community of inquirers there are moments approaching that of The Great Conversation and recognition that through communal effort participants can be relieved of unnecessary bias and other intellectual practices leading to error-ridden, conclusions (Wagner \& Lopez, 2010: pp. 167-172).

\section{Summary}

Classroom discussions that aim at modeling The Great Conversation must make clear there is an important point to the discussion ahead. The point is to advance knowledge by freeing participants from previous, wrong-headed thinking. Truth is certainly the ideal that all share and all should aim for. But while truth remains the shared ideal it is something of an eternal reward not to be had at the moment but only to be advanced upon.

A skillful community of inquirers sets out hypotheses and various speculations for critical review. The hypotheses and speculations that appear to be free of contradiction or violation of evidence to the contrary, are preserved for never ending evaluative, review in the future (Wagner et al., 2016).

\section{Conflicts of Interest}

The author declares no conflicts of interest regarding the publication of this paper.

\section{References}

Balter, M. (1998). Why Settle Down? The Mystery of Communities. Science, 20, 1442-1446. https://doi.org/10.1126/science.282.5393.1442

Chomsky, N. (2016). What Kind of Creatures Are We? New York: Columbia University Press. https://doi.org/10.7312/chom17596

Chomsky, N., \& Robichaud, A. (2014). Standardized Testing as an Assault on Humanism and Critical Thinking in Education. Radical Pedagogy, 1, 54-66.

Curry, A. (2008). Seeking the Roots of Ritual. Science, 319, 278-280. https://doi.org/10.1126/science.319.5861.278

Fair, F., Haas, L., Gardocki, C., Johnson, D., Price, D., \& Liepnik, O. (2015). Socrates in the Schools: Gains at Three-Year Follow-Up. Journal of Philosophy in Schools, 2, 5-16. https://doi.org/10.21913/JPS.v2i2.1268

Garrison, D. R. (2016). Thinking Collaboratively: Learning in a Community of Inquiry. New York: Routledge. https://doi.org/10.4324/9781315740751

Gilovich, T., \& Ross, L. (2015). The Wisest One in the Room. New York: Free Press.

Glass, G. (2016). One Hundred Years of Research: Prudent Aspirations. Educational Researcher, 45, 69-72. https://doi.org/10.3102/0013189X16639026

Gopnik, A. (2009). The Philosophical Baby: What Children's Minds Tell Us about Truth, Love, and the Meaning of Life. New York: Farrar, Straus, Giroux.

Gopnik, A. (2016). The Gardner and the Carpenter. New York: Picador.

Gopnik, A., Meltzoff, A. N., \& Kuhl, P. K. (1999). The Scientist in the Crib: What Early Learning Tells Us about the Mind. New York: Harper. 
Henrich, J. (2015). The Secret of Our Success. Princeton, NJ: Princeton University Press. https://doi.org/10.2307/j.ctvc77f0d

Jackson, P. (2011). What Is Education? Chicago, IL: University of Chicago Press.

Kahneman, D. (2011). Thinking Slow and Fast. New York, NY: Farrar, Straus \& Giroux.

Mann, C. C. (2011). The Birth of Religion. National Geographic Magazine, 219, 34-59.

Mlodinow, L. (2015). The Upright Thinkers. New York: Pantheon.

Nowak, M., Sasaki, C., \& Fudenberg, D. (2004). Emergence of Cooperation and Evolutionary Stability in Finite Populations. Nature, 428, 646-650.

https://doi.org/10.1038/nature02414

Pfaff, D. (2015). The Altruistic Brain. Oxford: Oxford University Press.

Pinker, S. (1994). The Language Instinct: How the Mind Creates the Gift of Language. New York: William Morrow. https://doi.org/10.1037/e412952005-009

Rakow, S. J. (1986). Teaching Science as Inquiry. Fastback 245. Bloomington, IN: Phi Delta Kappa Pub.

Ravitch, D. (2009). The Death and Life of the Great American School System. New York: Basic Books.

Sanderson, C. A. (2020). Why We Act: Turning Bystanders into Moral Rebels. Cambridge, MA: The Belknap Press of Harvard. https://doi.org/10.4159/9780674241817

Sigmund, K., Hauert, C., \& Nowak, M. (2001). Reward and Punishment. Proceedings of the National Academy of Sciences of the USA, 98, 10757-10762.

https://doi.org/10.1073/pnas.161155698

Siu, F. (2020). Mathematics for Human Flourishing. New Haven, CN: Yale University Press. https://doi.org/10.2307/j.ctvt1sgss

Sosa, E. (2009). Reflective Knowledge: Apt Belief and Reflective Knowledge, Volume II. New York: Oxford University Press. https://doi.org/10.1093/acprof:oso/9780199217250.001.0001

Thaler, R. (2015). Misbehaving: The Making of Behavioral Economics. New York, NY: Norton Pub.

Tomasello, M. (2014). A Natural History of Human Thinking. Cambridge, MA: Harvard University Press. https://doi.org/10.4159/9780674726369

Tomasello, M. et al. (2009). Why We Cooperate. Cambridge, MA: MIT Press. https://doi.org/10.7551/mitpress/8470.001.0001

Tomasello, M., \& Call, J. (1997). Primate Cognition. New York: Oxford University Press.

Wagner, P., \& Lopez, G. (2010). The Great Conversation and the Ethics of Inclusion. Multicultural Perspectives, 12, 167-172. https://doi.org/10.1080/15210960.2010.504496

Wagner, P., \& Simpson, D. (2008). Ethical Decision-Making in School Administration. San Francisco, CA: Sage.

Wagner, P., Johnson, D., Fair, F., \& Fasko, D. (2016). Thinking beyond the Test. Lanham, MD: Rowman \& Littlefield.

Wagner, P., Johnson, D., Fair, F., \& Fasko, D. (2018). Thinking Ahead. Lanham, MD: Rowman \& Littlefield.

Weisdorf, J. L. (2005). From Foraging to Farming: Explaining the Neolithic Revolution. Journal of Economic Surveys, 19, 562-586.

https://doi.org/10.1111/j.0950-0804.2005.00259.x

Wiley, R. (2015). Why Noise Matters. Cambridge, MA: Harvard University Press. https://doi.org/10.4159/9780674287044 